\title{
Effect of Pre-Harvest Spray of Chemicals on Quality, Yield and Storage Life of Litchi Fruits
}

\author{
Sushil Kumar Purbey*, Alemwati Pongener ${ }^{1}$ and Evening Stone Marboh ${ }^{2}$ \\ ${ }^{1}$ ICAR-MGIFRI, Motihari, Bihar-845429, India \\ ${ }^{2}$ ICAR-NRC on Litchi, Muzaffarpur, Bihar - 842002, India \\ *Corresponding author
}

\section{A B S T R A C T}

\section{Keywords}

Chemical,

Carbendazim, GA3,

Litchi fruit, Quality,

Spray, Yield

Article Info

Accepted:

04 September 2019

Available Online:

10 October 2019
Poor fruit set and retention followed by sun burning and cracking is a serious physiological disorder in litchi which is causing significant economic loss. Besides these, the pre-harvest quiescent infection with blight, anthracnose etc is also causing huge losses at post harvest stage. Considering these problems an experiment was conducted during 2010-13 to evaluate the effect of pre-harvest spray of various chemicals on fruit quality, yield and storage life of litchi fruits. Eight chemical treatments were sprayed twice on litchi fruits cv. Shahi, during fruit development stage and observations related to fruit retention, sun burning, cracking, fruit weight and other quality parameters were recorded and analyzed. The result showed that the combined spray of carbendazim $(0.2 \%)$ and $\mathrm{KNO}_{3}(4$ and $2 \%)$ gave the highest fruit yield $(26.06 \mathrm{~kg} / \mathrm{tree})$ and increased fruit retention by $26.10 \%$, whereas minimum fruit cracking and sun burning (13.54\%) was observed under combined spray of $\mathrm{GA}_{3}$ (50 and $100 \mathrm{ppm})$ and carbendazim $(0.2 \%)$. The minimum fruit yield $(18.01 \mathrm{Kg} /$ tree $)$ and maximum percentage of discarded fruits $(36.53 \%)$ were recorded in case of control (water spray). $\mathrm{KNO}_{3}$ treatments delayed the maturity of litchi fruits by 3.33 days whereas $\mathrm{GA}_{3}$ has advanced the maturity by 2.67 days and also gave uniform colour development. It has also been found that carbendazim treated fruits gave least decay loss $(5.56 \%)$ after 5 days of storage at ambient condition.

\section{Introduction}

Litchi, a member of soapberry family, is brightly coloured strawberry shaped fruits having thin leathery skin and sweet musky aroma. Litchi is now grown commercially in many countries and production in India, Australia, China, Israel, South Africa and Thailand has expanded markedly in recent years. Increased production has made significant contributions to economic development in these countries, especially those in South-East Asia. India ranks second accounts for 20 percent of word's litchi production. It is one of the most important commercial fruit crops of Bihar contributing significantly to the state economy. Being a non climacteric fruit, litchi fruit ripens on tree 
itself and reaches maturity approximately in 50-60 days after fruit set depending on the cultivar, environmental conditions and cultural practices. During fruit development, several problems like fruit set and retention in $1^{\text {st }}$ phase, sun burning, cracking and other quality parameters in $2^{\text {nd }}$ phase and poor shelf life after harvest are common which is causing considerable loss of yield and quality of litchi fruits in conventional method of litchi production. Only a small proportion (2-18\%) of it is carried to maturity in different cultivars. The flower and fruit drop is thought to be due to failure of fertilization, embryo abortion, nutrition and hormonal imbalance and external factors like high temperature, low humidity and strong westerly winds as well as due to insect pest and diseases. Studies revealed maximum fruit drop during the first fortnight after fruit set and at harvest the retention varies between 3.0-39.6\% among the cultivars. Under adverse conditions, the losses go to such an extent, that, it renders the litchi cultivation unprofitable to the growers. The disturbance in the endogenous hormonal level is one of the major contributing factors responsible for fruit drop Awasthi et al., (1975). Reduction in fruit drop with the application of growth substances was reported by Barua and Mohan (1984). Foliar spray of GA3 (20 ppm) was found effective treatment to increase fruit set, fruit retention and size of fruit, fruit weight and ultimately the fruit yield of litchi (Kumar et al., 2009).

$[\mathrm{K}+]$ cation plays a major role in enzyme activation, protein synthesis, stomatal function, stabilization of internal $\mathrm{pH}$, photosynthesis, turgor-related processes and transport of metabolites (Abd El Rahman and Hoda, 2016). When potassium uptake is lower than demand, foliar potassium is mobilized to the fruit, which is detrimental for plant growth, fruit set and quality (Besford and Maw, 1975). Similarly, Calcium is the cementing material in the matrix phase as it bridges pectin molecules at carboxylic groups through ionic bonds, and therefore contributes to the mechanical strength of the cell walls. In this way, calcium may contribute to fruit cracking resistance (Alani, 1980; Sekse and Ystaas, 1998).

The fruits may be contaminated in orchards right from the setting to harvesting stage leading to pre-mature fruit drop, and incipient pre-harvest infections causes subsequent postharvest decaying during storage and transit under cordial conditions of temperature and moisture (Naquvi et al., 1993). Latent or well established pre-harvest infection at the time of harvest is difficult to be abolished by mere post-harvest application of fungicides. Government regulations allow only preharvest employment of particular chemicals for decay control but not for the post-harvest treatment. The best approach to control the post-harvest fruit decaying is pre-harvest application of fungicides (Sharma, 1990). Preharvest or prophylactic fungicidal umbrella must be provided to overcome latent infection before the pathogen establishes in the host tissues particularly perishables intended to be kept under storage. Nowadays, the infection of Alterneria alternata starting from panicle stage to fruit level has been found very critical in litchi (Kumar, 2018). The application of carbendazim and other botanicals against early blight has been reported in India by various workers (Arunakumara et al., 2010; 2015, Kumar, 2018).

Since market for fresh litchi fruits is growing steadily, the needs for assuring high quality which can meet international standards are of vital importance to Indian Litchi industry. Considering, all these facts, the present study was carried out to test these chemicals which may favour the quality yield production as well as reducing microbial contamination after harvest to enhance the storage life of litchi fruits. 


\section{Materials and Methods}

The experiment was conducted in 8-10 years old litchi orchard during 2010-2013 consecutively for 3 years at Research Farm of ICAR-NRC on Litchi Muzaffarpur, Bihar located at $210 \mathrm{~m}$ MSL.

The experiment was laid out in randomized block design (RBD) comprising of 8 treatments viz. $\mathrm{T}_{1}: \mathrm{KNO}_{3}(4 \& 2 \%) ; \mathrm{T}_{2}: \mathrm{CaCl}_{2}$ $(0.1 \& 0.5 \%) ; \mathrm{T}_{3}: \mathrm{GA}_{3}(50 \& 100 \mathrm{ppm}) ; \mathrm{T}_{4}$ : Carbendazim (0.1 \& 0.2\%); $\mathrm{T}_{5}: \mathrm{T}_{1}+\mathrm{T}_{4} ; \mathrm{T}_{6}: \mathrm{T}_{2}$ $+\mathrm{T}_{4} ; \mathrm{T}_{7}: \mathrm{T}_{3}+\mathrm{T}_{4} ; \mathrm{T}_{8}:$ Control (Water spray) with three replications.

Two spray of each chemical was applied during fruit growth and developmental stage. The first spray was done just one week after fruit set and second just before aril development stage.

Standard cultural practices were followed to grow the litchi crops. The soil of experimental field was sandy loam in texture, alkaline in reaction with low to medium in fertility status.

Four fruits bunches in each side of the tree were tagged and fruit retained in each bunches under study were counted prior to first application of spray and also at the time of harvesting.

Finally, the fruit retention per cent was worked out. Similarly the average fruit weight was estimated by weighing 25 fruits in each treatment, with the help of an electronic balance and then converting to average fruit weight. Total soluble solids (TSS) were determined with Erma Hand Refractometer (0320 Brix) with necessary temperature correction.

The titratable acidity percentage of juice was estimated as per AOAC (2000). The sun burned and cracked fruits under each treatment were also counted and these fruits were categorized as discarded fruits. Discarded fruits percent was worked out. Fruit maturity (harvest date) was determined on the basis of fruit colour developed (a bright pinkish red blush with flattened tubercles) and pulp TSS reached $18^{\circ}$ Brix.

After harvesting, sorting and grading was done and fruits under each treatments were packed in perforated polyethylene bags and kept in $2 \mathrm{Kg}$ CFB boxes for post harvest study at ambient condition. The decay percentage, microbial load, TSS and firmness of the fruits were analysed after 5 days of storage. The haemocytometer is used for counting the fungal spores in liquid suspension. It is a special microscope slide with a counting chamber $0.1 \mathrm{~mm}$ deep so that volume of liquid over a one square $\mathrm{mm}$ is 0.1 cubic $\mathrm{mm}$.

The counting chamber has a total of nine squares, each of $1 \mathrm{~mm} \times 1 \mathrm{~mm}$ engraved over it but only one square per field is visible under 100x microscope magnification. Each one $\mathrm{mm}$ square is divided into 25 medium sized squares, each one of which is further sub divided into 16 small squares, thus a total of 400 squares in one $\mathrm{mm}$.

One milliliter $(\mathrm{ml})$ of a cell suspension is put into the counting chamber, number of cells is counted and the total cell number is determined mathematically $($ Spores $/ \mathrm{ml}=$ Number of spores counted on the middle square of the grid $x$ 104). Fruit firmness was measured by using a stand penetrometer of 0 $20 \mathrm{~kg}$ scale (Deccan Techno Corporation). A plunger of $6 \mathrm{~mm}$ diameter was used for the determination of rupture force and the readings were expressed as $\mathrm{kg} / \mathrm{cm}^{2}$. The data were subjected to statistical analysis as per the method of Gomez and Gomez (1984). Least significant of difference at 5\% level was used for finding the significance of differences if any, among the treatment means. 


\section{Results and Discussion}

The pooled mean data of 2010-2013 is presented in the results.

\section{Effect on quality and yield}

The observations on fruit retention percentage, discarded fruits, fruit weight, TSS, acidity and yield /tree were recorded and the findings obtained are presented in Table 1. It reveals that all the pre-harvest spray of chemicals significantly influenced all the quality parameters. The fruit retention has increased by $26.10 \%$ with treatment $\mathrm{T}_{5}$, followed by $\mathrm{T}_{7}$ and $\mathrm{T}_{6}$. Singh et al., (1999), also observed that Blitox $(0.1 \%)+2,4-\mathrm{D} 10 \mathrm{ppm}$ retained the maximum fruits closely followed by Bavistin $(0.1 \%)+2$, 4-D (10 ppm) in Kinnow mandarin. The combined spray of 2, 4-D 10 ppm + Carbendazim $0.1 \%$ gave highest fruit retention and fruit yield of Nagpur mandarin (Patil et al., 2011). The foliar spray of various concentrations of chemicals particularly $\mathrm{GA}_{3}$ and $\mathrm{CaCl}_{2}$ had pronounced effect on reducing the fruit cracking and sun burning. Significantly minimum discarded fruits (13.54 $\%)$ were recorded with treatment $\mathrm{T}_{7}$ followed by $\mathrm{T}_{6}$ and $\mathrm{T}_{3}$. The results are in close conformity with the findings of Mishra et al., (2012 \& 2017), who observed that the preharvest application of $\mathrm{GA}_{3}$ was most effective in minimizing fruit drop and fruit cracking and improving the physico-chemical properties and yield of litchi. Similarly, Qiu et al., (2000) reported that trees treated with a high-Ca (132 mg L-1) nutrient solution produced only $15.4 \%$ cracked fruit, while untreated trees produced 47.2\%. Huang et al., (2005) observed that single spray of different formulations of calcium at three developmental stages showed that the application of calcium at early fruit development stage (two weeks after anthesis) was most effective, followed by the application prior to aril expansion.
The data on average fruit weight showed significant variations. Fruits of $\mathrm{T}_{8}$ (control) showed minimum fruit weight of $18.38 \mathrm{~g}$. whereas, maximum fruit weights of $22.53 \mathrm{~g}$ in $\mathrm{T}_{7}$ followed by $22.17 \mathrm{~g}$ in $\mathrm{T}_{3} . \mathrm{T}_{1}$ and $\mathrm{T}_{5}$ were statistically at par with T3. Results related to TSS revealed that although all the treatments improved the TSS in comparison to control, the highest TSS was found in $\mathrm{GA}_{3}$ and their combined spray treatments (19.25 ${ }^{\circ}$ Brix $)$. Mishra et al., (2012 \& 2017) also reported improvement in yield and TSS with the application of $\mathrm{GA}_{3}$ in litchi. One of the other possible reasons for increased yield may be due to de-novo biosynthesis of auxin and other growth regulating or promoting chemicals at initial stage due to additional stimulus produced by external application of PBRs and chemicals. Hizazi et al., (1983) also observed that 50 and 200 ppm GA3 sprayed after 30 days of fruit set or 60 days of fruit set resulted in increase in fruit number and yield in pear.

Data presented in table 1 reveal that the plant growth regulators and fungicides significantly influenced the yield. Significantly maximum yield $\left(\left(26.06 \mathrm{Kg} /\right.\right.$ tree) was recorded with $\mathrm{T}_{5}$ followed by $\mathrm{T}_{7}(25.88 \mathrm{Kg} /$ tree $)$ which is at par with $\mathrm{T}_{5}$. The similar trend was also reported by Patil et al., (2011) in Nagpur mandarin. In the present study, the plant growth regulators and fungicide used has favoured the yield promoting factors, such as higher fruit retention and higher fruit weight, may lead to the increase in yield. One of the other possible reasons for increased yield may be due to role of fungicide and nitrogen in controlling the fruit drop by providing resistance against diseases. Spraying of $T_{1}$ and their combination delayed the harvesting by 3.67 days whereas application of $\mathrm{GA}_{3}$ and their combination has advanced the maturity by 2.33 days. Spray of $1 \%$ potassium nitrate led to largest fruit and delayed the harvesting due to its effect in supplementing the nitrogen to the leaves (Kumar et al., 2017). 
Table.1 Effect of various chemicals on quality and yield of litchi fruits (2010-2013 pooled data)

\begin{tabular}{|c|c|c|c|c|c|c|c|c|}
\hline Treatments & $\begin{array}{l}\text { Avg. } \\
\text { Fruit } \\
\text { wt. (g) }\end{array}$ & $\begin{array}{c}\text { Discarded } \\
\text { fruit* } \\
(\%)\end{array}$ & $\begin{array}{c}\text { Increase in } \\
\text { fruit } \\
\text { retention }(\%)\end{array}$ & $\begin{array}{l}\text { TSS } \\
\left({ }^{0} \mathrm{~B}\right)\end{array}$ & $\begin{array}{l}\text { Acidit } \\
\text { y (\%) }\end{array}$ & $\begin{array}{l}\text { Harve } \\
\text { sting } \\
\text { delay }\end{array}$ & $\begin{array}{c}\text { Harvesting } \\
\text { advancement }\end{array}$ & $\begin{array}{c}\text { Fruit yield } \\
\text { (Kg/ tree) }\end{array}$ \\
\hline $\mathbf{T}_{1}$ & 21.08 & 20.64 & 18.71 & 18.45 & 0.73 & 3.33 & & 24.81 \\
\hline $\mathbf{T}_{2}$ & 19.28 & 18.31 & 11.26 & 18.60 & 0.64 & & & 20.88 \\
\hline $\mathbf{T}_{3}$ & 22.17 & 16.27 & 10.79 & 19.05 & 0.48 & & 2.67 & 23.59 \\
\hline $\mathbf{T}_{4}$ & 18.92 & 21.96 & 19.71 & 18.10 & 0.60 & & & 21.83 \\
\hline $\mathbf{T}_{5}$ & 21.66 & 19.05 & 26.10 & 18.65 & 0.71 & 3.67 & & 26.06 \\
\hline $\mathbf{T}_{6}$ & 20.17 & 16.12 & 19.93 & 18.80 & 0.63 & & & 23.23 \\
\hline $\mathbf{T}_{7}$ & 22.53 & 13.54 & 21.25 & 19.25 & 0.50 & & 2.67 & 25.88 \\
\hline $\mathbf{T}_{8}$ & 18.38 & 36.53 & 00.00 & 18.05 & 0.55 & & & 18.01 \\
\hline CD at $5 \%$ & 1.06 & 1.27 & - & 0.47 & 0.13 & & & 2.14 \\
\hline
\end{tabular}

*Sun burned + cracked fruits

$\mathrm{T}_{1}: \mathrm{KNO} 3(4 \& 2 \%) ; \mathrm{T}_{2}: \mathrm{CaCl}_{2}(0.1 \& 0.5 \%) ; \mathrm{T}_{3}: \mathrm{GA}_{3}(50 \& 100 \mathrm{ppm}) ; \mathrm{T}_{4}:$ Carbendazim $(0.1 \& 0.2 \%) ; \mathrm{T}_{5}: \mathrm{T} 1+$ $\mathrm{T} 4 ; \mathrm{T}_{6}: \mathrm{T} 2+\mathrm{T} 4 ; \mathrm{T}_{7}: \mathrm{T} 3+\mathrm{T} 4 ; \mathrm{T}_{8}$ : Control (Water spray)

Table.2 Effect of various chemicals on post harvest life of litchi fruits (2010-2013 pooled data)

\begin{tabular}{|c|c|c|c|c|}
\hline Treatments & Decay loss (\%) & $\begin{array}{l}\text { Microbial load } \\
\quad(\text { cfu/ml })\end{array}$ & $\operatorname{TSS}\left({ }^{\circ} \mathrm{B}\right)$ & $\begin{array}{r}\text { Firmness } \\
\left(\mathrm{Kg} / \mathrm{cm}^{2}\right)\end{array}$ \\
\hline $\mathbf{T}_{1}$ & 18.84 & 10.81 & 18.80 & 1.46 \\
\hline $\mathbf{T}_{2}$ & 20.00 & 12.70 & 18.85 & 1.34 \\
\hline $\mathbf{T}_{\mathbf{3}}$ & 21.12 & 13.09 & 19.25 & 1.26 \\
\hline $\mathbf{T}_{4}$ & 07.18 & 06.56 & 18.30 & 1.36 \\
\hline $\mathbf{T}_{5}$ & 05.56 & 05.73 & 18.90 & 1.51 \\
\hline $\mathbf{T}_{6}$ & 06.67 & 07.08 & 19.05 & 1.40 \\
\hline $\mathbf{T}_{7}$ & 07.10 & 06.92 & 19.40 & 1.25 \\
\hline $\mathbf{T}_{8}$ & 23.34 & 15.17 & 18.15 & 1.31 \\
\hline CD at $5 \%$ & 3.17 & 1.15 & 0.46 & 0.12 \\
\hline
\end{tabular}

There is little information concerning the influence of $\mathrm{GA}_{3}$ on advancement of maturity.

\section{Effect on post harvest storage life}

The data presented in the Table 2 reveals that decay loss and microbial load was significantly affected by the treatments specially carbendazim and their combinations. Decay loss was observed minimum (5.56 and $6.67 \%$ ) in fruits treated with $\mathrm{T}_{5}$ and $\mathrm{T}_{6}$ respectively. Similarly treatments with
Carbendazim and their combination had significant effect in reducing the microbial load (in range of 5.73 to $7.10 \mathrm{cfu} / \mathrm{ml}$ ) as compare to control which had shown maximum microbial load $(15.17 \mathrm{cfu} / \mathrm{ml})$. Similar effects of fungicide were observed by Beniwal et al., (2018) in Kinnow mandarin; Singh and Sharma (2011) in Kinnow and Sandhu and Singhrot (2011) in lemon. Preharvest application of fungicides has been used to lesser pre-harvest inoculums load and subsequent post-harvest decay in various 
citrus fruits (Blackarski et al., 2001). Chadha (2001) conducted a study on the efficacy of foliar sprays of Carbendazim before harvest in controlling the post harvest decaying of citrus fruits.

The firmness of the fruits followed a declining trend commensurate with the advancement in storage period. The fruit firmness was recorded maximum $\left(1.51 \mathrm{~kg} / \mathrm{cm}^{2}\right)$ in $\mathrm{T}_{5}$ followed by $\mathrm{T}_{1}$ and $\mathrm{T}_{6}\left(1.46\right.$ and $\left.1.41 \mathrm{Kg} / \mathrm{cm}^{2}\right)$ at $5^{\text {th }}$ day of storage.

The decline in the firmness might be due to moisture loss from the fruit cells. Softening of fruits is caused either by the breakdown of insoluble proto pectins into soluble pectin or by hydrolysis of starch (Muttoo et al., 1975). Fruit firmness diminishes as the degree of ripening increases due to the action of pectolytic enzymes (Muramastsu et al., 1996).

There was slight increase in TSS of the fruits under each treatment which might be due to break down of complex polysaccharides in to simple carbohydrate compound. Similar results were also observed during storage by Sonkar and Ladaniya (1999) in Nagpur mandarin.

Litchi is highly sensitive to climatic variation and typical sub tropical fruit crops which is very responsive to various plant growth substances and chemicals. It has been found that combined spray of fungicide and growth regulators twice during fruit growth and development stage have resulted in quality litchi production along with enhanced yield and shelf life at ambient condition. However, an integrated approach is required to be studied further for export quality litchi production along with these chemicals.

\section{References}

A.O.A.C. 2000. Official Methods of Analysis. $17^{\text {th }}$ edition, Association of
Official Analytical Chemist, Washington DC.

Abd El-Rahman, G.F. and Hoda, M. Mohamed. 2016. Physiological Studies on Improving Fruit Quality of valencia Orange Fruits. Global Journal Biol. Agri. Health Science. 5(2): 93-101.

Alani, K. 1980. Cracking of soft fruits: causes and protective measures. Obstbau. 5:276- 278 .

Arunakumara, K. T., Kulkarni, M. S., Thammaiah, N and Hegde, Y. 2010. Fungicidal management of early blight of tomato. Indian Phytopathology. 63: 96-97.

Awasthi RP, Tripathi BR, Singh A. 1975. Effect of foliar sprays of zinc on fruit drop and quality of litchi (Litchi chinensis Sonn.). Punjab Hort. Journal, 15(1-2):14-16.

Barua PC, Mohan NK. 1984. Effect of growth regulators on prevention of fruit drop in litchi (Litchi chinensis Sonn.). South Indian Hort. 4; 321(2):92.

Beniwal, V., Godara, A. K., Goyal, R. K. and Prince. 2018. Effect of Pre-harvest Application of Fungicides on Fruit Quality of Kinnow Mandarin Stored Under Ambient Conditions, Int. J. Pure App. Bioscience. 6(6): 278-286. doi: http://dx.doi.org/10.18782/23207051.6706

Besford, R.T. and Maw, G.A. 1975. Effects of potassium nutrition on tomato plant growth and fruit development. Plant Science. 42: 395-412.

Blackarski, R. W., Bartz, J. A., Xiao, C. L. and Legard, D. E. 2001. Control of post-harvest Botrytis fruit rot with preharvest fungicide applications in annual strawberry. Plant Disease. 85: 597-602.

Chadha, K. L., New horizons in production and post-harvest management of tropical and subtropical fruits. Indian J. Horticulture. 58:1-6 (2001). 
Dennis, C. 1977. Susceptibility of stored crop to microbial infection. Ann. App. Biology. 65: 431-434.

Hizazi AM, El-Hagah MH, El-Hagger SZ, Kasse AA. 1983. Physio-chemical characters of Le-conte pear fruit in relation to gibberellic acid effects. Minufiyer Journal Agric. Research. 7:281-299.

Huang, X., Wang, H.C., Li, J., Yuan, W., Yin, J., Lu, J., and Huang, H. B. 2005. An Overview of Calcium's Role in Lychee Fruit Cracking. In Proc. 2nd IS on Lychee, Longan, Rambutan \& Other Sapindaceae Plants Eds. N. Chomchalow and N. Sukhvibul Acta Hort. 665,

Kumar, A., Singh, S. K., Pandey, S.D. Patel, R.K., and Nath, V. 2017. Effect of Foliar Spray of Chemicals on Flowering and Fruiting in Litchi. Int. J. Curr. Microbiol. App. Sci. 6(5): 13371343. doi: https://doi.org/10.20546/ijcmas.2017.6 05.145.

Kumar, M., Kumar, R. and Singh, R. P. 2009. Effect of micronutrients and plant growth regulators on fruiting of litchi. International Journal of Agricultural Sciences. 6(2):521-524.

Kumar, V. 2018. Diseases of litchi and their management. Technical bulletin, pub. ICAR-NRC on Litchi, Muzaffarpur, Bihar,p 6.

Li, J.G., Gao, F.F., Huang, H.B., Tan, Y.W. and Luo, J.T. 1999. Preliminary studies on the relationship between calcium and fruit cracking in litchi fruit. Journal South China Agri. Univ. 20:45-49.

Mattoo, A. K., Murata, T., Pantastico, E. B., Chachiss, K., Ogata, K. and Phan, C. T 1975. Chemical changes during ripening and senescence. In: Postharvest Physiology, Handling and Utilization of Tropical and Subtropical
Fruits and Vegetables (Ed.Pantastico, E.B.). The AVI Publication. Co. Inc. pp: 103-27.

Mishra DS, Lal RL, Chand Satish. 2014. Delaying the harvesting period of litchi (Litchi chinensis Sonn.) cv.Rose Scented. Progressive Hort. 2014; 46(2):273-275.

Mishra, D. S., Kumar, P., and Kumar, R. 2012. Effect of GA3 and BA on fruit weight, quality and ripening of Rose Scented' litchi. HortFlora Research Spectrum. 1(1): 80-82.

Mishra, N. K., Kholiya, K., and Tewari, R. 2017. Effect of plant bio-regulators on quality and yield of litchi (Litchi Chinensis Sonn.) Cv. Rose Scented. International Journal of Chemical studies. 5 (6): 36-38.

Muramatsu, N., Takahara, T., Kojima, K. and Ogata, T. 1996. Relationship between texture and cell wall polysaccharides of fruit flesh in various species of citrus. HortScience. 31(1): 114-116.

Naqvi, S. A. M. H. 1993. Influence of pre- and post-harvest factors on export oriented production of Nagpur mandarin. Proc. Of Vasantrao Naik Memorial National Seminar on Agricultural ScienceExport oriented horticultural production. pp: 181- 185 .

Patil, N. B., Shedame, B. M. And Ingle, S. H. 2011. Effect of plant growth regulators and fungicides on pre-harvest fruit drop in Nagpur Mandarin. Asian Journal of Bio Science. 6 (1): 29-32.

Peng, J., Xi, J.B., Tang, X.D., Wang, Y.G., Si, X.M. and Chen, J.S. 2001. Effect of $\mathrm{Ca}(\mathrm{NO} 3) 2$ and GA spray on leaves on the fruit cracking of 'Nuomici' litchi. Acta Hort. Sinica. 28:348-350.

Qiu, Y.B., Ou, L.X., Xiang, X., Chen, J.Z. and Li, Z.Q. 2000. Effects of foliage spray of high calcium nutrient solutions on fruit retention and cracking in litchi and longan. Guangdong Hort. 1:21-22. 
Sandhu, S. S. and Singhrot, R. S. 1993. Effect of pre-harvest spray of growth regulator and fungicides on shelf life lemon cv. Baramasi-A Note. Haryana J. Hort. Science. 22: 204-206.

Sekse, L. and Ystaas, J. 1998. Fruit cracking mechanisms in sweet cherries (Prunus avium L.) - A review. Acta Hort. 468:637-648.

Sharma, R. L. 1990. Efficacy of pre-harvest fungicidal sprays in controlling postharvest diseases of china pear. Pl. Dis. Research. 5: 109-111.
Singh, S.N., Saini, H.S. and Ratnapal, H.S. 1999. Effect of growth regulators and fungicides on fruit retaintion in kinnow mandarian. Proc. International Sym. Citric. pp. 699-708.

Sonkar, R. K., and Ladaniya, M. S. 1999. Effect of pre-harvest sprays of ethephon, calcium acetate and carbendazim on rind, colour, abscission and shelf life of Nagpur mandarin (Citrus reticulata). Indian Journal of agric. Science. 69: 130-135.

\section{How to cite this article:}

Sushil Kumar Purbey, Alemwati Pongener and Evening Stone Marboh. 2019. Effect of PreHarvest Spray of Chemicals on Quality, Yield and Storage Life of Litchi Fruits. Int.J.Curr.Microbiol.App.Sci. 8(10): 207-214. doi: https://doi.org/10.20546/ijcmas.2019.810.021 